\title{
Effects of salt stress on the physiological characteristics of Solanum photeinocarpum
}

\author{
Renyan Liao*, Yinsong Xu \\ Ya'an Polytechnic College, Ya'an, Sichuan 625000, China
}

\begin{abstract}
A pot experiment was used to study the effects of different concentrations of salt $(100,200,300$ $\mathrm{mmol} / \mathrm{L}$ ) stress on the photosynthetic physiology and antioxidant enzyme activities of Solanum photeinocarpum. The results showed that $\mathrm{NaCl}$ of 100 and $200 \mathrm{mmol} / \mathrm{L}$ could significantly improve the contents of chlorophyll $a$, chlorophyll $b$ and carotenoid in S. photeinocarpum. However, under different concentrations of salt stress, there was no significant difference in the amount of total chlorophyll in $S$. photeinocarpum. Besides, as the salt stress increased, the net photosynthetic rate, stomatal conductance, $\mathrm{CO}_{2}$ concentration of intercellular and transpiration rate of $S$. photeinocarpum gradually decreased, when the concentration of $\mathrm{NaCl}$ was $300 \mathrm{mmol} / \mathrm{L}$, reached the lowest value. With the increase of salt stress, the POD activity, CAT activity and soluble sugar content of $S$. photeinocarpum increased first and then decreased, reaching the highest when the concentration of $\mathrm{NaCl}$ was $100 \mathrm{mmol} / \mathrm{L}$. Therefore, $S$. photeinocarpum had a certain salt tolerance, low concentration of $\mathrm{NaCl}(\leq 200 \mathrm{mmol} / \mathrm{L})$ stress could promote its growth, but high concentration $(>200 \mathrm{mmol} / \mathrm{L}$ ) could inhibit its growth.
\end{abstract}

\section{Introduction}

Soil salinization is an important cause of land degradation and soil fertility decline [1], which not only causes serious waste of resources, but also has a serious impact on the ecological environment and social and economic development [2]. China's salinized soil area is about 34.6 million ha, and the salinized cultivated land is 7.6 million ha. About $20 \%$ of the cultivated land is salinized, which is mainly distributed in arid, semi-arid areas and coastal areas [3, 4]. Soil salinization will cause the osmotic pressure of the soil solution to increase, and the aeration of the soil will become poor, which affects the absorption of water by plants, which in turn affects the growth of plants [5]. Studies have found that with the increase of salt stress, the chlorophyll content of Tamarix chinensis increases first and then decreases [6]. When Paspalum vaginatum is treated with different concentrations of $\mathrm{NaCl}$ solution, the chlorophyll content and antioxidant enzyme activity shows a trend of increasing first and then decreasing with the increase of salt concentration [7]. For tomato, the low salt concentration $(0 \%-0.2 \%)$ conditions have little effect on seed germination, seedling growth and root tip micronucleus rate; when the salt concentration is higher than $0.3 \%$, the seed germination, seedling growth status, or root tip micronucleus are inhibited by salt [8].

Solanum photeinocarpum is an annual herb that grows in fields, roadsides and other places. Its tender stems can be used as edible wild vegetables. The taste is sweet, tender and delicious. At the same time, the roots, stems and leaves of $S$. photeinocarpum can be used as medicine $[9,10]$. This experiment studied the effects of different concentrations of salt (100, 200, $300 \mathrm{mmol} / \mathrm{L}$ ) stress on the growth and physiological characteristics of $S$. photeinocarpum, and explored the adaptive mechanism of $S$. photeinocarpum to salt stress.

\section{Materials and method}

\subsection{Materials}

The S. photeinocarpum seeds used in the experiment were collected from the farmland around the Yucheng District, Ya'an City, Sichuan Province, China. The substrate used in the experiment was coconut brick: perlite: soil $=1: 1: 1$.

\subsection{Experimental design}

In September 2020, sown the S. photeinocarpum seeds in 32-hole plug trays, and when the seedlings grow to 3-4 $\mathrm{cm}$, transplant them into $8 \mathrm{~cm} \times 10 \mathrm{~cm}$ (diameter $\times$ height) plastic pots, and three plants were planted in each pot. After transplanting, Hoagland solution was watered for nutrient solution culture. When the seedlings grow to about $15 \mathrm{~cm}$ ( 8 true leaves unfolded), salt stress was applied. A total of four $\mathrm{NaCl}$ concentration gradients were set, respectively, including 0 (CK), 100, 200, and $300 \mathrm{mmol} / \mathrm{L}$. One pot was one repetition, and 4 repetitions. The plants were placed in large trays containing different salt solutions. The solutions in the

\footnotetext{
*Corresponding author. E-mail: 51699474@qq.com
} 
trays were changed every 2 days for a total of 7 days. After 7 days, their physiological and biochemical indexes were measured.

In October 2020, the LI-6400 portable photosynthesis meter was used to determine the photosynthesis of $S$. photeinocarpum. The photosynthesis parameters of the photosynthesis instrument are manually controlled with a $\mathrm{CO}_{2}$ concentration of $400 \mu \mathrm{mol} / \mathrm{mol}$, a temperature of $30^{\circ} \mathrm{C}$, and a light intensity of $1000 \mu \mathrm{mol} / \mathrm{m}^{2} / \mathrm{s}$. The photosynthetic parameters include net photosynthetic rate $(\mathrm{Pn})$, transpiration rate (Tr), stomatal conductance (Gs), and intercellular $\mathrm{CO}_{2}$ concentration (Ci). After that, selected the upper mature leaves of $S$. photeinocarpum to determine the content of photosynthetic pigments (chlorophyll $a$, chlorophyll $b$, total chlorophyll and carotenoids) content, and selected the young leaves of $S$. photeinocarpum to determine antioxidant enzymes [superoxide dismutase (SOD), peroxidase (POD), and catalase (CAT) ] activity and soluble protein content. A $0.200 \mathrm{~g}$ leaf sample was cut into pieces and soaked in $20 \mathrm{~mL}$ of a $1: 1 \mathrm{v} / \mathrm{v}$ mixture of ethanol and acetone in the dark for $24 \mathrm{~h}$, then the absorbances at 663, 645, 652, and $470 \mathrm{~nm}$ (for chlorophyll $a$, chlorophyll $b$, total chlorophyll, and carotenoids, respectively) were measured according to the methods of Hao et al. [11]. A $1.0 \mathrm{~g}$ aliquot of fresh leaf tissue was added to $6 \mathrm{~mL}$ extraction buffer $(0.05 \mathrm{M}$ potassium phosphate buffer containing $1 \mathrm{mM}$ EDTA at $\mathrm{pH} 7.0$ ) at $4{ }^{\circ} \mathrm{C}$, and the mixture was homogenized and then centrifuged at $11000 \mathrm{~g}$ for $20 \mathrm{~min}$. The activities of SOD, POD, and CAT were measured by the nitroblue tetrazolium reduction method, guaiacol method, and potassium permanganate titration method, respectively, and the soluble protein content was measured by the Coomassie brilliant blue method [11].

\subsection{Statistical analyses}

Statistical analyses were conducted using SPSS 20.0 (IBM, Chicago, IL, USA). Data were subjected to one-way analysis of variance, followed by least significant difference test ( $5 \%$ confidence level).

\section{Results and discussion}

\subsection{Effect of salt stress on the photosynthetic pigment content in S. photeinocarpum}

With the increase of salt stress, the contents of chlorophyll $a$, chlorophyll $b$, carotenoid and total chlorophyll contents in $S$. photeinocarpum increased first and then decreased (Table 1). When the $\mathrm{NaCl}$ concentration was $200 \mathrm{mmol} / \mathrm{L}$, the contents of chlorophyll $a$ and chlorophyll $b$ of $S$. photeinocarpum reached the maximum. Compared with the control, 100, 200 , and $300 \mathrm{mmol} / \mathrm{L} \mathrm{NaCl}$ concentrations increased the chlorophyll $a$ content in $S$. photeinocarpum by $26.35 \%$ ( $p$ $<0.05), 27.35 \%(p<0.05)$, and $8.40 \%(p<0.05)$, respectively, increased the chlorophyll $b$ content in $S$. photeinocarpum by $31.91 \%(p<0.05), 32.34 \%(p<$ $0.05)$, and $11.91 \%(p>0.05)$, respectively, and increased the total chlorophyll content in $S$. photeinocarpum by $27.72 \%(p<0.05), 28.46 \%(p<0.05)$, and $9.17 \%(p>$ $0.05)$, respectively. When the $\mathrm{NaCl}$ concentration was $100 \mathrm{mmol} / \mathrm{L}$, the carotenoid content of $S$. photeinocarpum reached the maximum. Compared with the control, 100, 200, and $300 \mathrm{mmol} / \mathrm{L} \mathrm{NaCl}$ concentrations increased the carotenoid content in $S$. photeinocarpum by $26.92 \%(p<0.05), 20.00 \%(p<$ $0.05)$, and $16.92 \%(p<0.05)$, respectively.

Table 1. The photosynthetic pigment content of S. photeinocarpum.

\begin{tabular}{|c|c|c|c|c|}
\hline $\begin{array}{c}\mathrm{NaCl} \\
(\mathrm{mmol} / \mathrm{L})\end{array}$ & $\begin{array}{l}\text { Chlorophyll } a \\
\text { (mg/g) }\end{array}$ & $\begin{array}{l}\text { Chlorophyll } b \\
\text { (mg/g) }\end{array}$ & $\begin{array}{l}\text { Carotenoid } \\
(\mathrm{mg} / \mathrm{g})\end{array}$ & $\begin{array}{l}\text { Total chlorophyll } \\
(\mathrm{mg} / \mathrm{g})\end{array}$ \\
\hline 0 & $0.702 \pm 0.006 \mathrm{c}$ & $0.235 \pm 0.004 b$ & $0.130 \pm 0.002 b$ & $0.938 \pm 0.010 \mathrm{~b}$ \\
\hline 100 & $0.887 \pm 0.020 \mathrm{a}$ & $0.310 \pm 0.012 \mathrm{a}$ & $0.165 \pm 0.007 \mathrm{a}$ & $1.198 \pm 0.032 \mathrm{a}$ \\
\hline 200 & $0.894 \pm 0.029 a$ & $0.311 \pm 0.012 \mathrm{a}$ & $0.156 \pm 0.012 \mathrm{a}$ & $1.205 \pm 0.041 \mathrm{a}$ \\
\hline 300 & $0.761 \pm 0.011 b$ & $0.263 \pm 0.017 \mathrm{~b}$ & $0.152 \pm 0.010 \mathrm{ab}$ & $1.024 \pm 0.029 b$ \\
\hline
\end{tabular}

Value are means \pm standard errors. Means with the same letter within each column are not significantly different at $p<$ 0.05 .

\subsection{Effect of salt stress on photosynthetic characteristics of S. photeinocarpum}

With the increase of the salt stress, the Pn, Gs, Ci and Tr of $S$. photeinocarpum gradually decreased (Table 2). When the $\mathrm{NaCl}$ concentration was $300 \mathrm{mmol} / \mathrm{L}$, the Pn, Gs, $\mathrm{Ci}$ and $\mathrm{Tr}$ of $S$. photeinocarpum reached the lowest level. Compared with the control, 100, 200, and 300 $\mathrm{mmol} / \mathrm{L} \mathrm{NaCl}$ concentrations reduced the $\mathrm{Pn}$ of $S$. photeinocarpum by $18.28 \%(p<0.05), 42.90 \%$ ( $p<$ $0.05)$, and $64.90 \%(p<0.05)$, respectively, reduced the Gs of $S$. photeinocarpum by $16.21 \%(p<0.05), 48.38 \%$ $(p<0.05)$, and $72.32 \%(p<0.05)$, respectively, reduced the $\mathrm{Ci}$ of $S$. photeinocarpum by $15.04 \%(p<0.05)$, $33.29 \%(p<0.05)$, and $42.98 \%(p<0.05)$, respectively, and reduced the $\operatorname{Tr}$ of $S$. photeinocarpum by $19.79 \%(p<$ 
$0.05), 34.29 \%(p<0.05)$, and $43.33 \%(p<0.05)$, respectively. Salt stress of different concentrations significantly reduced the $\mathrm{Pn}, \mathrm{Gs}, \mathrm{Ci}$ and $\mathrm{Tr}$ of $S$. photeinocarpum, and the differences between the treatments were significant.

Table 2. Photosynthetic characteristics of $S$. photeinocarpum.

\begin{tabular}{|c|c|c|c|c|}
\hline $\begin{array}{c}\mathrm{NaCl} \\
(\mathrm{mmol} / \mathrm{L})\end{array}$ & $\begin{array}{c}\mathrm{Pn} \\
\left(\mu \mathrm{mol} \mathrm{CO} / \mathrm{m}^{2} / \mathrm{s}\right)\end{array}$ & $\begin{array}{c}\mathrm{Gs} \\
\left(\mathrm{mol} \mathrm{H} \mathrm{H}_{2} \mathrm{O} / \mathrm{m}^{2} / \mathrm{s}\right)\end{array}$ & $\begin{array}{c}\mathrm{Ci} \\
(\mu \mathrm{mol} \mathrm{CO} / \mathrm{mol})\end{array}$ & $\begin{array}{c}\operatorname{Tr} \\
\left(\mathrm{mmol} \mathrm{H}{ }_{2} \mathrm{O} / \mathrm{m}^{2} / \mathrm{s}\right)\end{array}$ \\
\hline 0 & $9.268 \pm 0.312 \mathrm{a}$ & $0.401 \pm 0.001 \mathrm{a}$ & $338.5 \pm 1.93 a$ & $4.083 \pm 0.174 \mathrm{a}$ \\
\hline 100 & $7.574 \pm 0.127 b$ & $0.336 \pm 0.013 b$ & $287.6 \pm 7.29 b$ & $3.275 \pm 0.101 b$ \\
\hline 200 & $5.292 \pm 0.110 \mathrm{c}$ & $0.207 \pm 0.009 \mathrm{c}$ & $225.8 \pm 5.71 \mathrm{c}$ & $2.683 \pm 0.069 \mathrm{c}$ \\
\hline 300 & $3.253 \pm 0.093 \mathrm{~d}$ & $0.111 \pm 0.007 \mathrm{~d}$ & $193.0 \pm 7.45 \mathrm{~d}$ & $2.318 \pm 0.020 \mathrm{~d}$ \\
\hline
\end{tabular}

Value are means \pm standard errors. Means with the same letter within each column are not significantly different at $p<$ 0.05 .

\subsection{Effect of salt stress on antioxidant enzyme activity of $S$. photeinocarpum}

With the concentration of $\mathrm{NaCl}$ increase, the $\mathrm{SOD}$ activity of $S$. photeinocarpum gradually decreased (Table 3). When the $\mathrm{NaCl}$ concentration was $300 \mathrm{mmol} / \mathrm{L}$, the SOD activity of $S$. photeinocarpum reached the minimum value. Compared with the control, 100, 200, and $300 \mathrm{mmol} / \mathrm{L} \mathrm{NaCl}$ concentrations reduced the SOD activity of $S$. photeinocarpum by $18.57 \%(p<0.05)$, $29.07 \%(p<0.05)$, and $35.23 \%(p<0.05)$, respectively. The POD activity, CAT activity and soluble protein content of $S$. photeinocarpum showed a trend of first increasing and then decreasing. When $\mathrm{NaCl}$ concentration was $100 \mathrm{mmol} / \mathrm{L}$, the POD activity, CAT activity and soluble protein content of $S$. photeinocarpum reached the maximum value. Compared with the control, 100,200 , and $300 \mathrm{mmol} / \mathrm{L} \mathrm{NaCl}$ concentrations enhanced the POD activity of $S$. photeinocarpum by 58.07\% $(p<0.05), 49.00 \%(p<0.05)$, and $10.95 \%(p<$ $0.05)$, respectively, and increased the soluble protein content of $S$. photeinocarpum by $35.26 \%(p<0.05)$, $17.75 \%(p<0.05)$, and $11.49 \%(p<0.05)$, respectively. The concentration of $100 \mathrm{mmol} / \mathrm{L} \mathrm{NaCl}$ enhanced the CAT activity of $S$. photeinocarpum by $8.74 \%(p<0.05)$ compared with the control. However, the concentrations of 200 and $300 \mathrm{mmol} / \mathrm{L} \mathrm{NaCl}$ reduced the CAT activity of $S$. photeinocarpum by $9.76 \%(p<0.05)$ and $22.15 \%(p$ $<0.05)$, respectively, compared with the control.

Table 3. Antioxidant enzyme activity of $S$. photeinocarpum.

\begin{tabular}{|c|c|c|c|c|}
\hline $\begin{array}{c}\mathrm{NaCl} \\
(\mathrm{mmol} / \mathrm{L})\end{array}$ & $\begin{array}{l}\text { SOD activity } \\
(\mathrm{U} / \mathrm{g})\end{array}$ & $\begin{array}{l}\text { POD activity } \\
\text { (U/g/min) }\end{array}$ & $\begin{array}{l}\text { CAT activity } \\
\text { (mg/g/min) }\end{array}$ & $\begin{array}{l}\text { Soluble protein content } \\
(\mathrm{mg} / \mathrm{g})\end{array}$ \\
\hline 0 & $214.3 \pm 10.53 \mathrm{a}$ & $849 \pm 24.88 \mathrm{c}$ & $4.92 \pm 0.21 \mathrm{~b}$ & $30.46 \pm 0.49 c$ \\
\hline 100 & $174.5 \pm 9.14 b$ & $1342 \pm 29.85 \mathrm{a}$ & $5.35 \pm 0.11 \mathrm{a}$ & $41.20 \pm 1.71 \mathrm{a}$ \\
\hline 200 & $152.0 \pm 6.47 \mathrm{c}$ & $1265 \pm 16.79 a$ & $4.44 \pm 0.01 \mathrm{c}$ & $35.87 \pm 0.37 \mathrm{~b}$ \\
\hline 300 & $138.8 \pm 4.13 \mathrm{c}$ & $942 \pm 38.84 \mathrm{~b}$ & $3.83 \pm 0.10 \mathrm{~d}$ & $33.96 \pm 0.52 b$ \\
\hline
\end{tabular}

Value are means \pm standard errors. Means with the same letter within each column are not significantly different at $p<$ 0.05 .

\section{Conclusions}

In this experiment, low concentration of salt stress could promote the increase of chlorophyll $a$, chlorophyll $b$ and carotenoid content of $S$. photeinocarpum. But all the salt stress had no significant effect on the total chlorophyll of $S$. photeinocarpum. With the increase of the salt stress, the $\mathrm{Pn}, \mathrm{Gs}, \mathrm{Ci}$ and $\mathrm{Tr}$ of $S$. photeinocarpum gradually decreased, and the differences between treatments were significant. Compared with the control, the SOD activity of $S$. photeinocarpum decreased, and the POD activity, CAT activity and soluble protein content increased first and then decreased. Therefore, under the condition of salt stress, $S$. photeinocarpum could increase photosynthetic pigment content, and improve the photosynthetic characteristics and antioxidant enzyme activity to improve resistance to salt stress. 


\section{References}

1. Jing, Y.P., Duan, Y., Tuo, D.B., Zhao, P.Y., Zhang, J., Lu, S.Z. (2016) Characteristics of salinization of deserted farmland in Hetao Plain, China. Acta Pedol. Sin., 53: 1410-1420.

2. Jing, Y.P., Lian, H.F., Li, Y.J., Li, X.P., Gao, W., Di, C.X., Li, Y.F., Kang, W.Q. (2020) Analysis on the Difference of Soil Salinization Characteristics in Hetao saline-alkali soil with different land use. J. Soil Water Conserv., 34: 354-363.

3. Che, W.P., Hou, Z.N., Wu, L.S., Liang, Y.C., Wei, C.Z. (2010) Evaluating salinity distribution in soil irrigated with saline water in arid regions of northwest China. Agr Water Manage., 97: 2001-2008.

4. Jia, Y., Xiang, Y.F., Wang, L.L., Zhao, J., Liu, C.L., Pan, Z.Y. (2020) Effects of salt stress on the growth and physiological characteristics of Primula forbesii. Acta Pratac. Sin., 29: 119-128.

5. Lu, Y.M., Su, C.Q., Li, H.F. (2013) Effects of different salts stress on seed germination and seedling growth of Trifolium repens. Acta Pratac. Sin., 22:123-129.
6. Zhu, J.F., Liu, J.T., Lu, Z.H., Xia, J.B., Liu, H.N., Jin, Y. (2015) Effects of salt stress on physiological characteristics of Tamarix chinensis Lour. seedlings. Acta Ecol. Sin., 35: 5140-5146.

7. Jia, X.P., Deng, Y.M., Sun, X.B., Liang, L.J. (2015) Impacts of salt stress on the growth and physiological characteristics of Paspalum vaginatum. Acta Pratac. Sin., 24: 204-212.

8. Dai, W.M., Cai, R., Pan, J.S., He, H.L. (2002) Effects of salt stress on growth development of tomato. Acta Agriculturae Shanghai, 18: 58-62.

9. Li, Y.Y., Huang, L.H., Chen, X.W. (2006) Analysis of nutritional components on natural plant Solanum photeinocarpum $\mathrm{Na}$ Kamura et Odashima. Chin. Agric. Sci. Bull., 22:101-102.

10. Wu, C.F., Bao, R.F., Liao, H.P., Liu, P., Sun, J., Liao, M.A., Lin, L.J., Ren, W. (2018) Selenium accumulation characteristics of wild vegetable Solanum photeinocarpum. J. Sichuan Agric. Univ., 36: 778-784.

11. Hao, Z.B., Cang, J., Xu, Z. (2004) Plant physiology experiment. The Polytechnic University of Harbin Press, Harbin, China. 